\title{
ANALISIS PERBANDINGAN JEMBATAN PELAT CONTINUOUS SPAN BENTANG PENDEK DENGAN SISTEM KONVENSIONAL DAN PRATEGANG
}

\author{
Timotius $^{1}$ dan Edison Leo ${ }^{2}$ \\ ${ }^{1}$ Program Studi Sarjana Teknik Sipil, Universitas Tarumanagara, Jl. Letjen S. Parman No.1 Jakarta \\ Email: timobudi@gmail.com \\ ${ }^{2}$ Program Studi Sarjana Teknik Sipil, Universitas Tarumanagara, Jl. Letjen S. Parman No.1 Jakarta \\ Email: edisonl@ft.untar.ac.id
}

\begin{abstract}
ABSTRAK
Jembatan merupakan sarana konstruksi yang cukup penting bagi kelancaran ekonomi dan aliran perjalanan. Jembatan memiliki fungsi sebagai sarana konstruksi untuk menghubungkan suatu tempat dengan tempat lainnya yang sulit untuk dijangkau. Salah satu jenis jembatan bedasarkan bentuk strukturnya adalah jembatan pelat. Jembatan pelat atau slab bridge tersusun dari pelat monolit, dengan bentang dari tumpuan menuju ke tumpuan tanpa didukung oleh balok melintang ataupun balok girder atau balok gelagar, sehingga pelat tersebut hanya ditopang oleh abutment jembatan Dalam perencanaannya, penulangan jembatan dapat didesain dengan sistem konvensional ataupun prategang. Beton konvensional adalah beton normal yang tidak mengalami tegangan pra layan. Beton prategang merupakan beton yang dimana tulangan bajanya ditarik terhadap betonnya atau dengan kata lain diberikan tegangan pra-layan. Penelitian ini akan menganalisis perbandingan antara sistem konvensional dan prategang pada jembatan pelat dari segi ketebalan pelat dan lendutan. Analisis ini menggunakan bantuan program finite element untuk membuktikan hasil perhitungan manual dengan metode garis pengaruh. Hasil analisis menunjukkan bahwa dengan menggunakan sistem konvensional dan prategang akan menghasilkan ketebalan yang sama, walaupun lendutan yang dihasilkan lebih kecil dikarenakan batas lendutan ijin untuk beban live load yang sama untuk keduanya yaitu sebesar L/800. Sehingga apabila dimensi tebal-nya diperkecil, maka lendutan beban live load yang terjadi tidak memenuhi syarat lendutan ijin.
\end{abstract}

Kata kunci: Jembatan, Pelat, Konvensional, Prategang, Ketebalan, lendutan.

\section{PENDAHULUAN}

Tidak dapat dipungkiri, bahwa jembatan merupakan sarana transportasi yang sangat krusial bagi masyarakat Indonesia khususnya dalam hal kelancaran perekonomian serta dalam aliran perjalanan atau traffic flows. Jembatan sendiri merupakan suatu sarana konstruksi yang memiliki fungsi untuk menghubungkan suatu tempat dengan tempat lainnya yang sulit untuk dijangkau. Suatu tempat dikatakan sulit dijangkau karena kondisi geografis wilayah itu sendiri yang terputus oleh rintangan atau hambatan fisik seperti misalnya dibatasi oleh jurang, sungai, saluran irigasi dan sebagainya.

Bedasarkan tipe strukturnya, jembatan dibagi menjadi beberapa jenis. Salah satunya adalah jembatan pelat atau slab bridge. Jembatan pelat atau slab bridge tersusun dari pelat monolit, dengan bentang dari tumpuan menuju ke tumpuan tanpa didukung oleh balok melintang ataupun balok girder atau balok gelagar, sehingga pelat tersebut hanya ditopang oleh abutment jembatan. Pelat pada jembatan sendiri berfungsi untuk mendistribusikan beban-beban sepanjang bentang jembatan menuju abutment jembatan yang kemudian bebannya ditahan oleh pondasi. Suatu jembatan beton dengan struktur atas berupa slab atau pelat akan lebih efisien bila digunakan untuk bentang pendek (Supriyadi \& Muntohar, 2007). Suatu jembatan dikatakan bentang pendek apabila bentangnya masih dibawah $40 \mathrm{~m}$. Untuk bentang antara $40 \mathrm{~m}$ sampai $150 \mathrm{~m}$ biasanya disebut dengan jembatan bentang menengah dan yang lebih dari $150 \mathrm{~m}$, disebut dengan jembatan bentang panjang.

Pembuatan pelat lantai jembatan pada umumnya menggunakan cara konvensional, yaitu menggunakan beton dengan tulangan baja. Beton konvensional adalah beton normal yang tidak mengalami tegangan pra layan. Terdapat pula cara Beton prategang atau prestressed concrete yang umumnya lebih efisien dibandingkan cara konvensional. Beton prategang merupakan beton yang dimana tulangan bajanya ditarik terhadap betonnya atau dengan kata lain diberikan tegangan pra-layan. Penarikan tersebut menyebabkan keadaan seimbang pada tekanan dalam (tekan pada beton dan Tarik terhadap baja) yang meningkatkan kemampuan beton menahan gaya luar. Karena beton cukup kuat terhadap 
tekanan dan sebaliknya lemah terhadap gaya tarik maka kemampuan menahan beban luar dapat ditingkatkan dengan pemberian pratekanan (Collins \& Mitchell, 1991).

\section{Pembebanan}

Beban yang bekerja pada suatu jembatan, dibagi menjadi 3 kelompok, yaitu :

1. Berat sendiri,

2. Berat tambahan / ultilitas, dan

3. Beban lalu lintas. Dimana beban lalu lintas yang digunakan diambil yang terbesar diantara :

1. Beban lajur " $\mathrm{D}$ " terdiri atas :

Beban terbagi rata (BTR) mempunyai intensitas $\mathrm{q} \mathrm{kPa}$ dengan besaran $\mathrm{q}$ tergantung pada panjang total yang dibebani $\mathrm{L}$ Jika $\mathrm{L} \leq 30 \mathrm{~m}$ maka $\mathrm{q}=9.0 \mathrm{kPa}$. Beban garis terpusat (BGT) dengan intensitas $\mathrm{p} \mathrm{kN} / \mathrm{m}$ harus ditempatkan tegak lurus terhadap arah lalu lintas pada jembatan. Besarnya intensitas p adalah $49.0 \mathrm{kN} / \mathrm{m}$. Untuk mendapatkan momen lentur negatif maksimum pada jembatan menerus, BGT kedua yang identik harus ditempatkan pada posisi dalam arah melintang jembatan pada bentang lainnya.

2. Beban truk "T"

Pembebanan truk "T" terdiri atas kendaraan truk semi-trailer yang mempunyai susunan dan berat gandar seperti terlihat pada Gambar 1. Berat tiap-tiap gandar disebarkan menjadi 2 beban merata sama besar yang merupakan bidang kontak antara roda dengan permukaan lantai. Jarak antara 2 gandar tersebut bisa diubahubah dari $4.0 \mathrm{~m}$ sampai dengan 9,0 m untuk mendapatkan pengaruh terbesar pada arah memanjang jembatan.
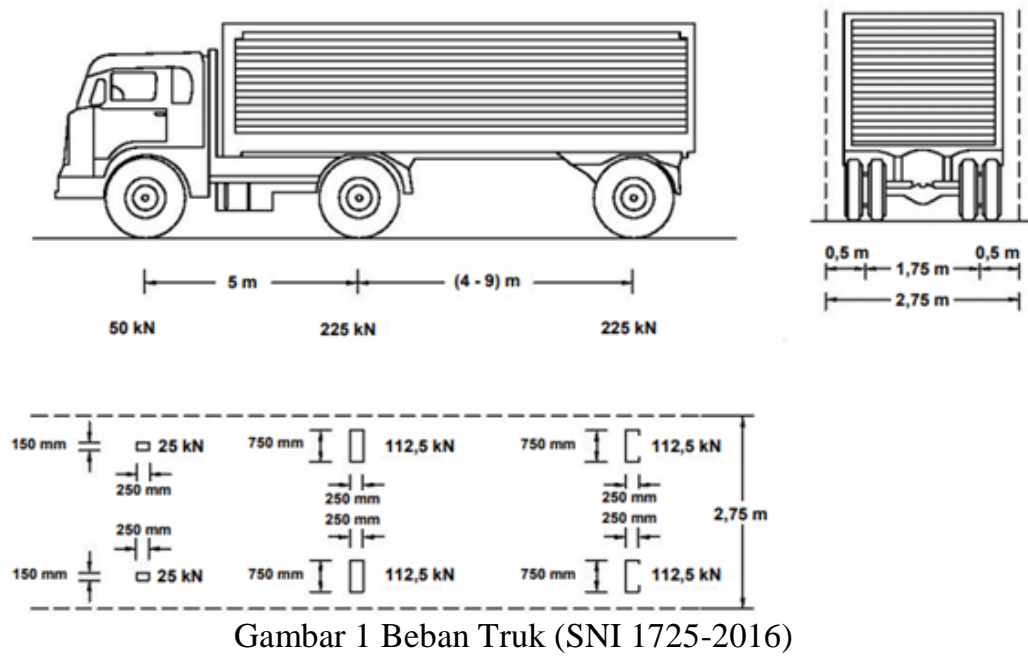

4. Impact Factor

Besarnya pembebanan lajur "D" dan truk "T" harus dikalikan dengan impact factor. Nilai dari impact tergantung dari panjang bentang seperti bisa dilihat pada Gambar 2.

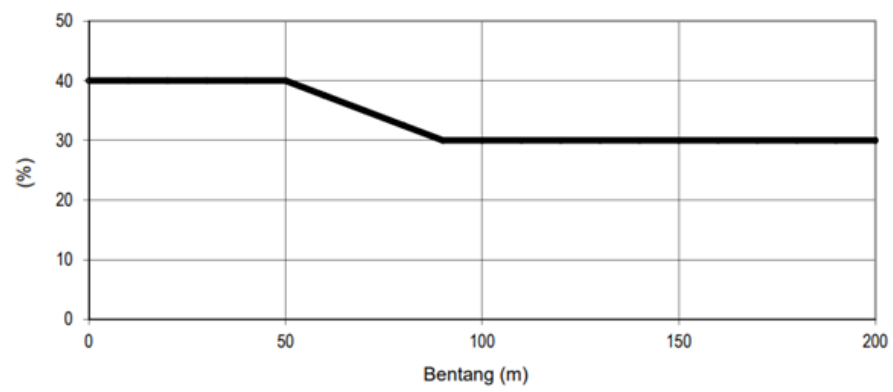

Gambar 2 Impact Factor (SNI 1725-2016)

\section{Beton konvensional}

Beton Konvensional merupakan kombinasi dari komponen beton serta tulangan baja. Kombinasi dari kedua ini membentuk suatu elemen dimana secara bersamaan mampu menahan beban yang bekerja pada suatu beton 
konvensional, dimana komponen beton menahan gaya tekan serta tulangan baja mempunyai fungsi untuk menahan gaya tarik atau lentur, dikarenakan komponen beton tidak cukup kuat untuk menahan gaya tarik (kuat tarik beton hanya 1/10 dari kuat tekannya). Suatu komponen struktur ketika dibebani secara tegak lurus terhadap sumbu panjangnya, maka akan mengalami kelenturan pada sumbu panjangnya. Lenturan pada struktur beton tersebut akan mengalami kerusakan yang ditandai dengan retak bila tidak ditahan dengan suatu bahan struktur, sehingga digunakanlah bahan baja yang berfungsi untuk memberikan ketahanan terhadap lentur yang terjadi.

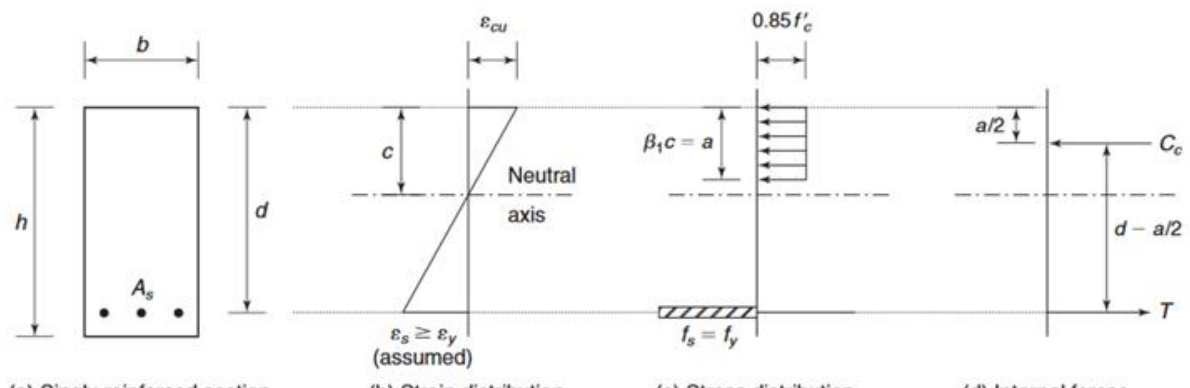

(a) Singly reinforced section.

(b) Strain distribution.

(c) Stress distribution

(d) Internal forces.

Fig. 4-18

Steps in analysis of $M_{n}$ for singly reinforced rectangular sections.

Gambar 3 Diagram Tegangan dan Regangan (Sumber : Reinforced Concrete Mechanics and Design)

\section{Beton prategang}

Beton prategang dapat didefinisikan sebagai beton yang diberikan tegangan tekan internal sedemikian rupa sehingga dapat meng-eliminir tegangan tarik yang terjadi akibat beban ekternal sampai suatu batas tertentu. Eugene Freyssinet menggambarkan dengan memberikan tekanan terlebih dahulu (pratekan) pada bahan beton yang pada dasarnya getas akan menjadi bahan yang elastis. Dengan memberikan tekanan (dengan menarik baja mutu tinggi), beton yang bersifat getas dan kuat memikul tekanan, akibat adanya tekanan internal ini dapat memikul tegangan tarik akibat beban eksternal. Hal ini dapat dilihat pada Gambar 4.
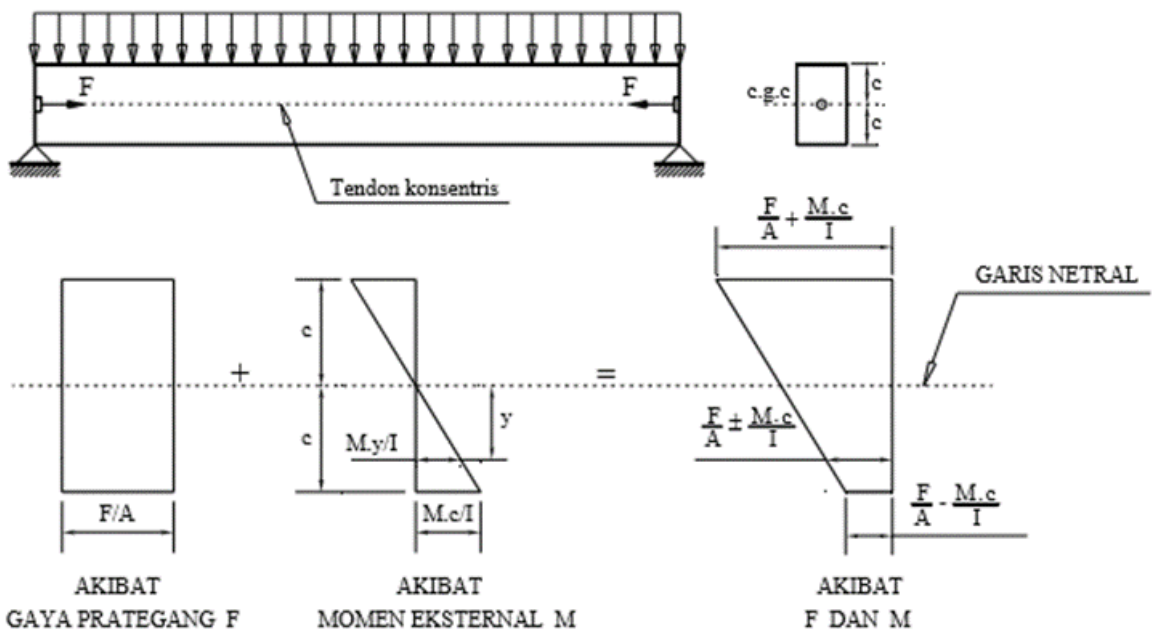

Gambar 4 Konsep Prategang (Beton Prategang : Suatu Pendekatan Mendasar)

Akibat diberi gaya tekan (gaya prategang) F yang bekerja pada pusat berat penampang beton akan memberikan tegangan tekan yang merata diseluruh penampang beton sebaesar F/A, dimana A adalah luas penampang beton tersebut. Akibat beban merata (termasuk berat sendiri beton) akan memberikan tegangan tarik dibawah garis netral dan tegangan tekan diatas garis netral pada serat terluar penampang.

\section{Lendutan pada jembatan}

Menurut RSNI-T-12-2004, Lendutan balok dan pelat akibat beban layan harus dikontrol sebagai berikut : 
a) Geometrik dan penampang harus direncanakan untuk melawan lendutan akibat pengaruh tetap sehingga sisa lendutan (positif atau negatif) masih dalam batas yang dapat diterima.

b) Agar lendutan tidak mengganggu tampak dari struktur, lendutan akibat pengaruh tetap yang diberikan pada Peraturan Pembebanan untuk Jembatan Jalan Raya harus sedemikian rupa sehingga pada bagian tengah bentang tidak melebihi $1 / 300$ bentang dan tidak terjadi lendutan.

c) Lendutan akibat beban rencana untuk daya layan pada Peraturan Pembebanan untuk Jembatan Jalan Raya tidak melampaui $1 / 250$ bentang.

d) Lendutan akibat beban hidup layan termasuk kejut harus dalam batas yang sesuai dengan struktur dan kegunaanya. Kecuali dilakukan penyelidikan lebih lanjut, dan tidak melampaui L/800 untuk bentang dan L/400 untuk kantilever.

\section{METODOLOGI PENELITIAN}

Penelitian ini dilakukan berdasarkan hasil analisis dengan bantuan program finite element serta dengan perhitungan manual. Dalam melaksanakan analisis, langkah-langkah yang ditempuh penulis digambarkan melalui diagram alir penelitian seperti pada Gambar 5 .

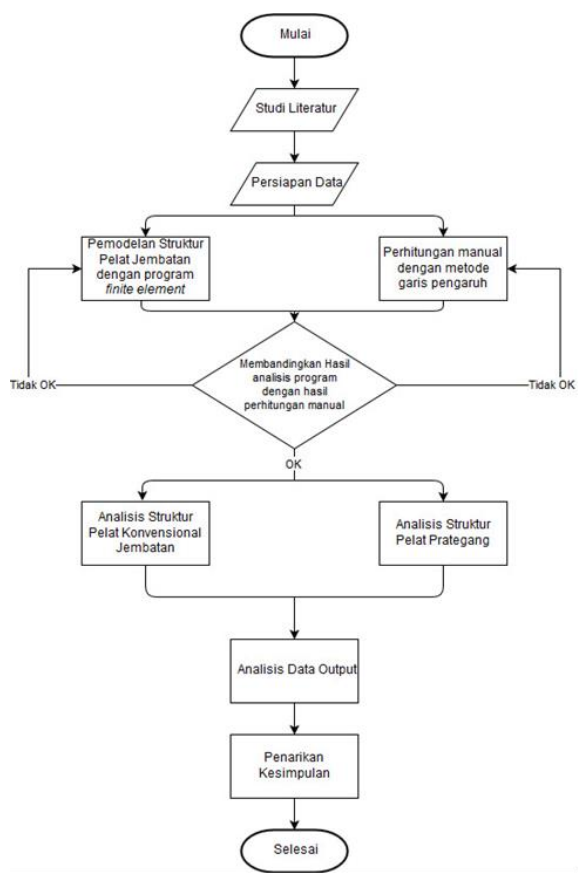

Gambar 5. Diagram Alir Penelitian

\section{ANALISIS DAN PEMBAHASAN}

\section{Model jembatan}

Model jembatan yang dianalisis dapat dilihat pada Gambar 6. Jembatan terdiri atas 3 span, dimana panjang masingmasing span berurutan adalah $8 \mathrm{~m}, 12 \mathrm{~m}$ dan $8 \mathrm{~m}$., lebar jembatan $7 \mathrm{~m}$.
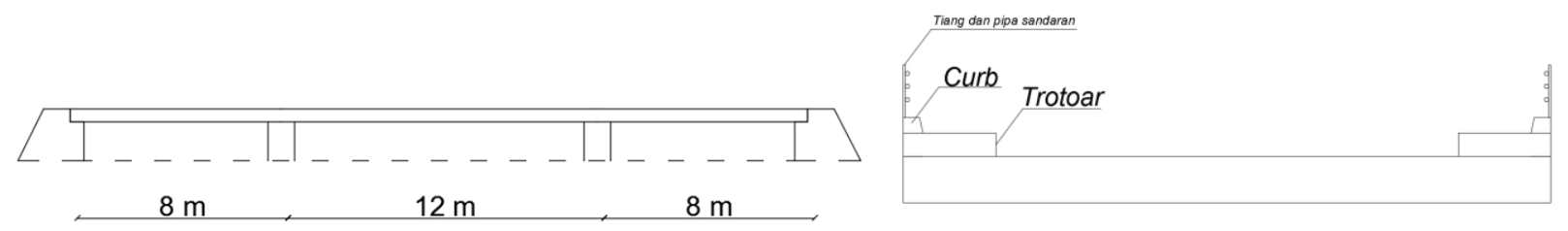

$7 \mathrm{~m}$

Gambar 6 Model Jembatan Tampak samping dan Tampak depan 


\section{Spesifikasi teknis}

- Tebal slab

Menurut RSNI T-12-2004, Tebal slab harus memenuhi syarat :

○ Tebal $\mathrm{Slab} \geq 200 \mathrm{~mm}$, dan

○ Tebal Slab $\geq(100+40 * \mathrm{~L}) \mathrm{mm}$.

Sehingga Tebal slab yang diperoleh adalah $=100+(40 * 12)=580 \mathrm{~mm}$ atau $0.58 \mathrm{~m}$

- Tebal lapisan aspal $\quad=0.1$ meter

- Tebal aspal beton tambahan $\quad=0.05$ meter (SNI 1725-2016)

- Dimensi Curb
- Lebar Curb
$=0.6$ meter
- Tebal Curb
$=0.3$ meter
- Panjang sisi atas
$=0.2$ meter
- Panjang sisi bawah
$=0.25$ meter

- Dimensi Trotoar
- Tinggi Trotoar
$=0.25$ meter
- Panjang Trotoar
$=1$ meter
- Berat Pipa dan Tiang sandaran $\quad=1.5 \mathrm{kN} / \mathrm{m}$

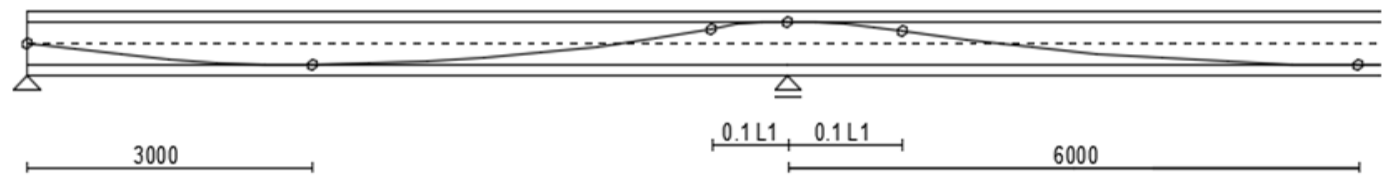

Gambar 7 Sketsa Penempatan Tendon

\section{Spesifikasi material}

- $\quad$ Beton (Slab)

Kuat Tekan Beton (f'c) $\quad=40 \mathrm{MPa}$

Modulus Elastis Beton $(\mathrm{Ec}) \quad=29725.41 \mathrm{MPa}$

Berat Jenis Beton Normal $\quad=24 \mathrm{kN} / \mathrm{m} 3$

Berat Jenis Beton Prategang $\quad=25 \mathrm{kN} / \mathrm{m} 3$

- Beton (Curb)

Kuat Tekan Beton (f'c) $\quad=25 \mathrm{MPa}$

Berat Jenis Beton $\quad=22 \mathrm{kN} / \mathrm{m} 3$

- Tulangan Baja

Kuat Leleh Baja (fy) $\quad=400 \mathrm{MPa}$

Modulus Elastis Baja (Es) $\quad=200000 \mathrm{MPa}$

- $\quad$ Strand Properties (Grade 270 ASTM A416-06)

Nominal Diameter $(\mathrm{d}) \quad=12,7 \mathrm{~mm}$

Nominal Cross Section (Ap) $\quad=98,7 \mathrm{~mm} 2$

Nominal Mass $(\mathrm{M}) \quad=0,775 \mathrm{~kg} / \mathrm{m}^{\prime}$

Nominal Tensile Strength $(\mathrm{fpk}) \quad=1860 \mathrm{MPa}$

Minimum Breaking Load $\quad=183.7 \mathrm{kN}$

Modulus Young = $\quad 1,95 \times 103 \mathrm{GPa}$

- Allowable Stress

$$
\begin{aligned}
& \mathrm{fci}=0.8 \times \mathrm{fc}^{\prime}=0.8 \times 40=32 \mathrm{MPa} \\
& \text { - Transfer } \\
& \text { Tekan } \quad=0,6 \mathrm{fci}=19.2 \mathrm{MPa} \\
& \text { Tarik } \quad=0,25(\mathrm{fci})^{0,5}=2.828 \mathrm{MPa} \\
& \text { - Service } \\
& \text { Tekan } \\
& =0,45 \mathrm{f}^{\prime} \mathrm{c}=18 \mathrm{MPa}
\end{aligned}
$$




\section{Hasil analisis}

Metode Konvensional (dengan tebal $580 \mathrm{~mm}$ )

- Momen Lapangan Bentang Tengah

Tabel 1 Momen Ultimate Lapangan Bentang Tengah

\begin{tabular}{ccccc}
\hline No & Jenis Beban & Mmax Lapangan & Faktor & Mu lapangan mid \\
\hline 1 & Beban Mati Sendiri & 101.992 & 1.30 & 132.589 \\
\hline 2 & Beban Mati Tambahan & 42.989 & 2.00 & 85.977 \\
\hline 3 & Live Load (Truck Load) & 198.464 & 1.80 & 357.235 \\
\hline 4 & Impact & 59.539 & 1.80 & 107.170 \\
\hline & Total & & 682.971 \\
\hline
\end{tabular}

Tulangan Utama

Tulangan Pembagi

Lendutan Akibat beban Dead Load

Lendutan Akibat beban Live Load

Lendutan total ( $\delta$ tot)

$$
\begin{aligned}
& =\mathrm{D} 25-125 \mathrm{~mm} \\
& =\mathrm{D} 25-200 \mathrm{~mm} \\
& =3.2 \mathrm{~mm}(<40 \mathrm{~mm}) \\
& =6.3 \mathrm{~mm}(<15 \mathrm{~mm}) \\
& =14.28 \mathrm{~mm}(<48 \mathrm{~mm})
\end{aligned}
$$

Tabel 2 Momen Ultimate Tumpuan

\begin{tabular}{ccccc}
\hline No & Jenis Beban & Mmax Tumpuan & Faktor & Mu Tumpuan \\
\hline 1 & Beban Mati Sendiri & -148.568 & 1.30 & -193.139 \\
\hline 2 & Beban Mati Tambahan & -62.620 & 2.00 & -125.240 \\
\hline 3 & Live Load (Truck Load) & -152.127 & 1.80 & -273.829 \\
\hline 4 & Impact & -45.638 & 1.80 & -82.149 \\
\hline & Total & & & -674.356 \\
\hline
\end{tabular}

Tulangan Utama

Tulangan Pembagi

$$
\begin{aligned}
& =\mathrm{D} 25-125 \mathrm{~mm} \\
& =\mathrm{D} 25-200 \mathrm{~mm}
\end{aligned}
$$

\section{Perhitungan Metode Konvensional Efektif}

Karena dicari tebal slab yang efektif, maka tebal slab dicoba menggunakan ketebalan dengan rentang antara $0.58 \mathrm{~m}$ sampai $0.35 \mathrm{~m}$. Gambar 8 menjelaskan pengaruh tebal pelat terhadap lendutan yang terjadi akibat beban dead load, live load, dan beban total.
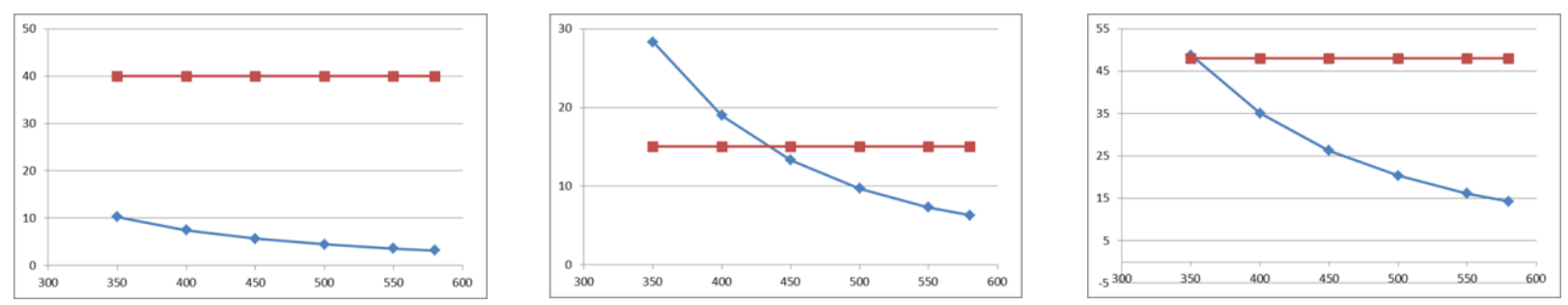

Gambar 8 Lendutan akibat beban dead load (kiri), live load (tengah), dan beban total (kanan) (biru) dibandingkan dengan lendutan ijin akibat beban dead load (kiri), live load (tengah), dan beban total (kanan) (merah).

Sehingga dari gambar dapat disimpulkan, untuk tebal efektif slab digunakan tebal $450 \mathrm{~mm}$. 
- $\quad$ Momen Lapangan Bentang Tengah

Tabel 3 Momen Ultimate Lapangan Bentang Tengah

\begin{tabular}{|c|c|c|c|c|}
\hline No & Jenis Beban & Mmax Lapangan & Faktor & Mu Lapangan \\
\hline 1 & Beban Mati Sendiri & 79.1316 & 1.3 & 102.87108 \\
\hline 2 & Beban Mati Tambahan & 42.98855571 & 2 & 85.97711143 \\
\hline 3 & Live Load (Truck Load) & 198.4636364 & 1.8 & 357.2345455 \\
\hline 4 & Impact & 59.53909091 & 1.8 & 107.1703636 \\
\hline & Total & & 653.2531005 \\
\hline
\end{tabular}

Tulangan Utama

Tulangan Pembagi

Lendutan Akibat beban Dead Load

Lendutan Akibat beban Live Load

Lendutan total ( $\delta$ tot)
$=\mathrm{D} 25-100 \mathrm{~mm}$

$=\mathrm{D} 25-250 \mathrm{~mm}$

$=5.7 \mathrm{~mm}(<40 \mathrm{~mm})$

$=13.3 \mathrm{~mm}(<15 \mathrm{~mm})$

$=26.22 \mathrm{~mm}(<48 \mathrm{~mm})$

- $\quad$ Momen Tumpuan

Tabel 4 Momen Ultimate Tumpuan

\begin{tabular}{|c|c|c|c|c|}
\hline No & Jenis Beban & Mmax Tumpuan & Faktor & Mu Tumpuan \\
\hline 1 & Beban Mati Sendiri & -115.2684 & 1.3 & -149.84892 \\
\hline 2 & Beban Mati Tambahan & -62.62001571 & 2 & -125.2400314 \\
\hline 3 & Live Load (Truck Load) & -152.1272727 & 1.8 & -273.8290909 \\
\hline 4 & Impact & -45.63818182 & 1.8 & -82.14872727 \\
\hline & Total & & -631.0667696 \\
\hline
\end{tabular}

Tulangan Utama

$=\mathrm{D} 25-100 \mathrm{~mm}$

Tulangan Pembagi

$=\mathrm{D} 25-250 \mathrm{~mm}$

Metode Prestressed (dengan tebal $580 \mathrm{~mm}$ )

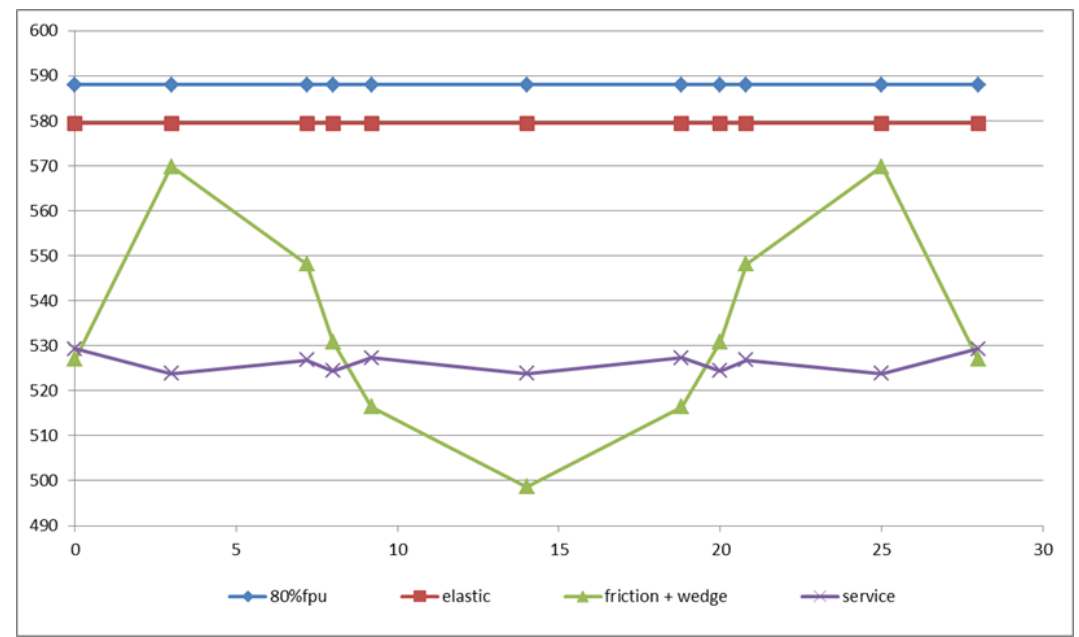

Gambar 9 Losses yang terjadi pada penampang prategang 

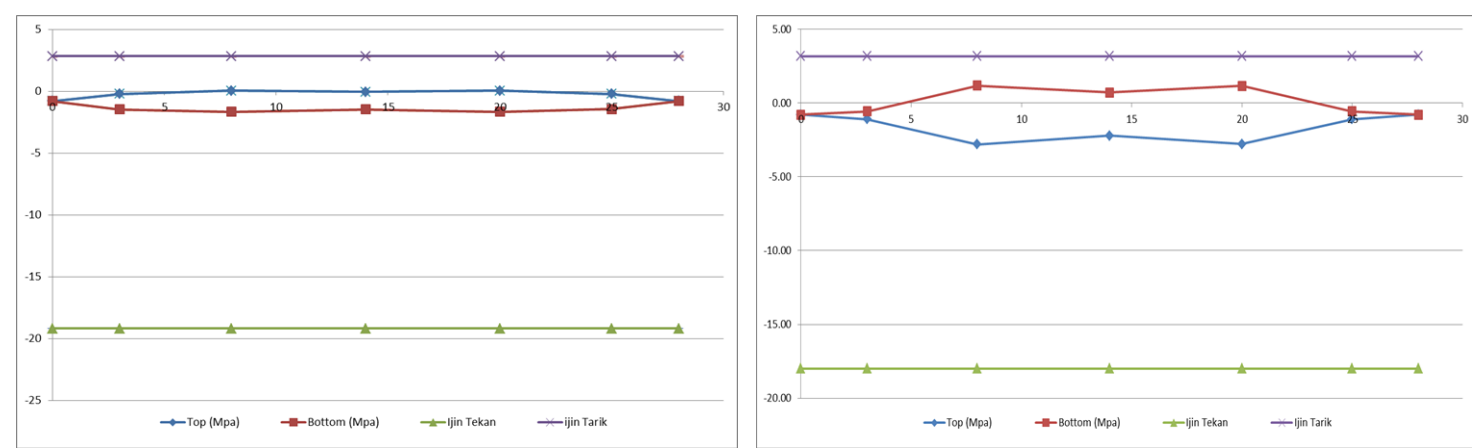

Gambar 10 Tegangan serat atas dan bawah pada kondisi transfer (kiri) dan service (kanan) yang terjadi pada penampang prategang dibandingkan dengan tegangan ijin.

Tabel 5 Lendutan yang terjadi pada penampang prategang

\begin{tabular}{ccccc}
\hline Jarak & DL $(\mathbf{m m})$ & LL $(\mathbf{m m})$ & TRANSFER $(\mathbf{m m})$ & SERVICE $(\mathbf{m m})$ \\
\hline 0 & 0 & 0 & 0 & 0 \\
\hline 3 & 0.5 & 2.3 & -0.5 & 1.9 \\
\hline 14 & 3.3 & 6.3 & 1.1 & 8.4 \\
\hline 25 & 0.5 & 2.3 & -0.5 & 1.9 \\
\hline 28 & 0 & 0 & 0 & 0 \\
\hline
\end{tabular}

Tabel 6 Lendutan yang diijinkan

\begin{tabular}{ccc}
\hline & TUMPUAN & LAPANGAN \\
\hline DL & 26.67 & 40 \\
\hline LL & 10 & 15 \\
\hline TRANSFER & 32 & 48 \\
\hline SERVICE & 32 & 48 \\
\hline
\end{tabular}

\section{Perhitungan Metode Prestressed Efektif}

Karena dicari tebal slab yang efektif, maka tebal slab dicoba menggunakan ketebalan dengan rentang antara $0.58 \mathrm{~m}$ sampai $0.35 \mathrm{~m}$. Gambar 11 dan 12 menjelaskan pengaruh tebal pelat terhadap lendutan yang terjadi akibat beban dead load, live load, kondisi transfer, dan kondisi service.
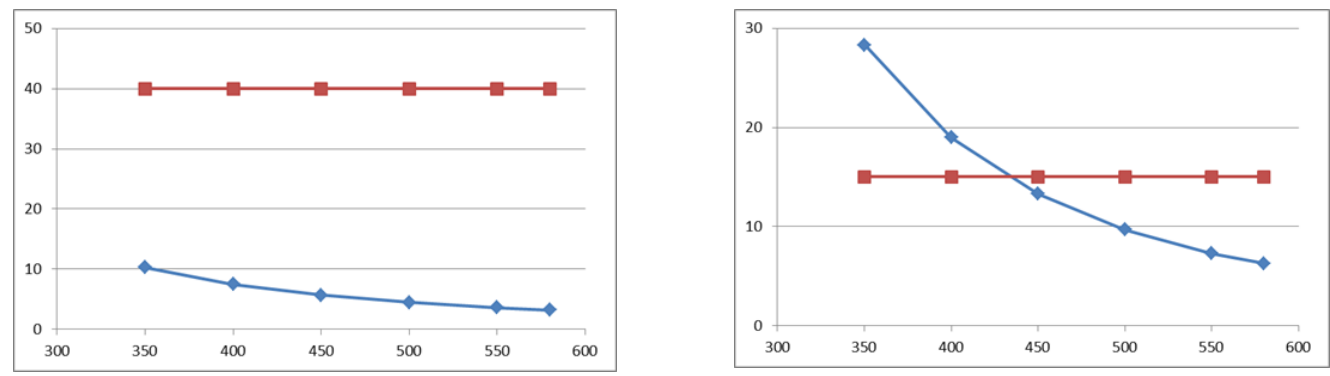

Gambar 11 Lendutan akibat beban dead load (kiri) dan live load (kanan) (biru) dibandingkan dengan lendutan ijin akibat beban dead load (kiri) dan live load (kanan) (merah). 

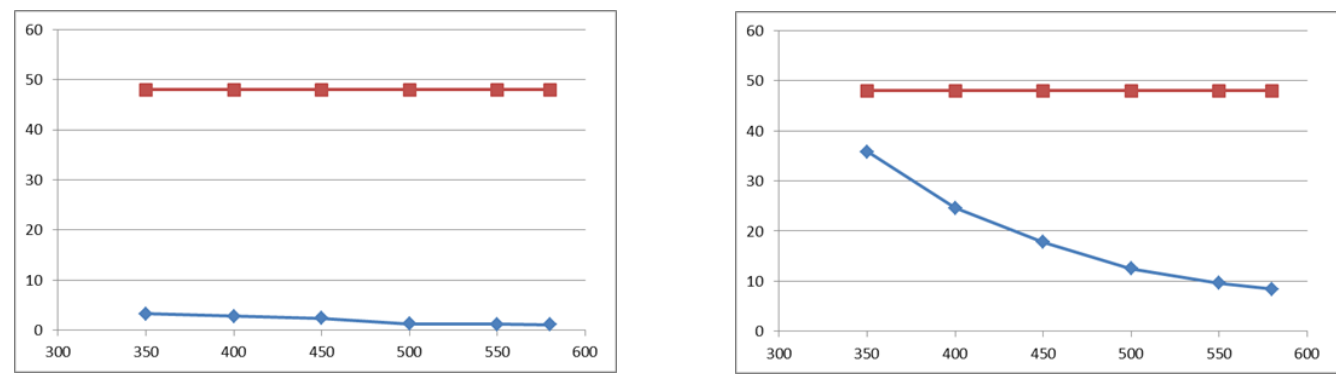

Gambar 12 Lendutan akibat kondisi transfer (kiri) dan service (kanan) (biru) dibandingkan dengan lendutan ijin akibat kondisi transfer (kiri) dan service (kanan) (merah).

Sehingga dari gambar dapat disimpulkan, untuk tebal efektif slab digunakan tebal $450 \mathrm{~mm}$.

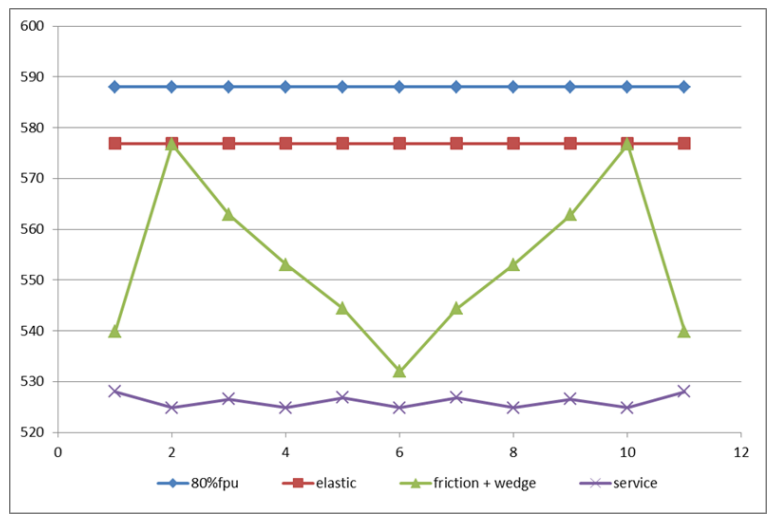

Gambar 13 Losses yang terjadi pada penampang prategang
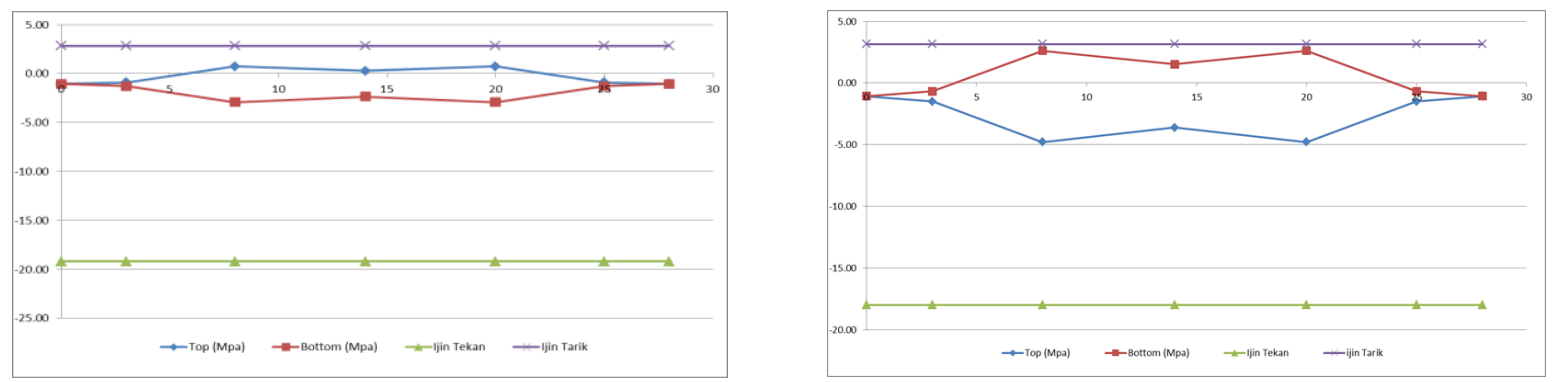

Gambar 14 Tegangan serat atas dan bawah pada kondisi transfer (kiri) dan service (kanan) yang terjadi pada penampang prategang dibandingkan dengan tegangan ijin.

Tabel 7 Lendutan yang terjadi pada penampang prategang

\begin{tabular}{ccccc}
\hline Jarak & DL $(\mathbf{m m})$ & LL $(\mathbf{m m})$ & TRANSFER $(\mathbf{m m})$ & SERVICE $(\mathbf{m m})$ \\
\hline 0 & 0 & 0 & 0 & 0 \\
\hline 3 & 1 & 4.8 & -0.4 & 4.8 \\
\hline 14 & 5.9 & 13.3 & 2.4 & 17.8 \\
\hline 25 & 1 & 4.8 & -0.4 & 4.8 \\
\hline 28 & 0 & 0 & 0 & 0 \\
\hline
\end{tabular}


Tabel 8 Lendutan yang diijinkan

\begin{tabular}{ccc}
\hline & TUMPUAN & LAPANGAN \\
\hline DL & 26.67 & 40 \\
\hline LL & 10 & 15 \\
\hline TRANSFER & 32 & 48 \\
\hline SERVICE & 32 & 48 \\
\hline
\end{tabular}

\section{KESIMPULAN DAN SARAN}

\section{Kesimpulan}

Berdasarkan analisis yang dilakukan, didapatkan beberapa kesimpulan sebagai berikut:

1. Dengan menggunakan beton sistem prategang, lendutan total yang dihasilkan akan menjadi lebih kecil ketimbang menggunakan beton sistem konvensional.

2. Dalam penilitian ini, beton prategang memiliki dimensi tebal yang sama dengan beton konvensional, walaupun lendutan yang dihasilkan lebih kecil dikarenakan batas lendutan ijin untuk beban live load yang sama untuk keduanya yaitu sebesar L/800. Sehingga apabila dimensi tebal-nya diperkecil, maka lendutan beban live load yang terjadi tidak memenuhi syarat lendutan ijin.

\section{Saran}

Berdasarkan kesimpulan yang telah dibuat, maka saran yang dapat diberikan yaitu:

1. Membuat permodelan jembatan secara utuh, yaitu membuat model jembatan secara menyeluruh baik struktur atas maupun struktur bawah agar mendapatkan hasil yang lebih optimum.

2. Meskipun lendutan akibat sistem prestress lebih kecil dibandingkan sistem konvensional, dengan tebal slab yang sama, disarankan untuk memakai beton dengan sistem konvensional, karena selisih lendutan yang dihasilkan oleh kedua sistem tersebut tidak terlalu besar, yaitu kurang dari $10 \mathrm{~mm}$. Dari segi biaya, pemasangan dan pekerjaan di lapangan diperlukan penelitian lebih lanjut.

\section{DAFTAR PUSTAKA}

AASHTO. (2011). LRFD Bridge Design Specifications. AASHTO.

ACI COMMITTEE. (2011). Building Code Requirements fot Structural Concrete (ACI 318-11) and Commentary. American Concrete Institute.

Dipohusodo, Istimawan. (1996). Struktur Beton Bertulang. PT. Gramedia Pustaka Utama. Jakarta.

MNI-EC (2008). "Pehitungan Slab Lantai Jembatan Jembatan Srandakan Kulon Progo D.I. Yogyakarta". (https://dokumen.tips/documents/perhitungan-slab-lantai-jembatan.html. Diakses pada 15 Oktober 2018)

Nawy, Edward G., and H. Wibi. Hardani. (2001). Beton Prategang: Suatu Pendekatan Mendasar. Penerbit Erlangga. Soetoyo,Ir. (2011). "Konstruksi Beton Prategang".

(http://ardi.staff.gunadarma.ac.id/Downloads/files/40144/Beton+Prategangz.pdf. Diakses pada 3 September 2018).

Standar Nasional Indonesia. (2016). Pembebanan untuk Jembatan, SNI - 1725 - 2016, Badan Standarisasi Nasional, Bandung.

Standar Nasional Indonesia. (2004). Perencanaan struktur beton untuk jembatan, RSNI - T-12-2004, Badan Standarisasi Nasional, Bandung.

Supriyadi, Bambang dan Muntohar, Agus Setyo. (2007). Jembatan. Penerbit Beta Offset. Yogyakarta.

Wight, James K. dan Macgregor, James G. Reinforced Concrete. Pearson Education,Inc.

Zulkarnain dan Riza Y.A, Yusuf. (1997). Analisis dan Perencanaan Pelat Beton Prategang Dua Arah pada Panel Tunggal dengan Metode Perimbangan Beban. Thesis. 